\title{
Maternal Protein Restriction Suppresses the Newborn Renin-Angiotensin System and Programs Adult Hypertension in Rats
}

\author{
LORI L. WOODS, JULIE R. INGELFINGER, JENS R. NYENGAARD, AND RUTH RASCH \\ Division of Nephrology, Oregon Health Sciences University, Portland, Oregon 97201-3098, U.S.A. \\ [L.L.W.]; Pediatric Nephrology Unit, Massachusetts General Hospital, Boston, Massachusetts 02114, \\ U.S.A. [J.R.I.]; Department of Cell Biology, Institute of Anatomy [R.R] and Stereological Research \\ Laboratory [J.R.N.], University of Aarhus, Aarhus, Denmark
}

\begin{abstract}
Restriction of maternal protein intake during rat pregnancy produces offspring that are hypertensive in adulthood, but the mechanisms are not well understood. Our purpose was to determine whether this adult hypertension could be programmed during development by suppression of the fetal/newborn reninangiotensin system (RAS) and a consequent reduction in nephron number. Pregnant rats were fed a normal protein $(19 \%, \mathrm{NP})$ or low-protein $(8.5 \%$, LP) diet throughout gestation. Birth weight was reduced by $13 \%(p<0.0005)$, and the kidney/body weight ratio was reduced in LP pups. Renal renin mRNA levels were significantly reduced in newborn LP pups; renal renin concentration and renin immunostaining were suppressed. Renal tissue angiotensin II levels were also suppressed in newborn LP (0.079 $\pm 0.002 \mathrm{ng} / \mathrm{mg}$, LP versus $0.146 \pm 0.016 \mathrm{ng} / \mathrm{mg}, \mathrm{NP}, p<0.01)$. Mean arterial pressure in conscious, chronically instrumented adult offspring (21 wk) was higher in LP $(135 \pm 1 \mathrm{~mm} \mathrm{Hg}$, LP versus $126 \pm 1 \mathrm{~mm} \mathrm{Hg}$, NP, $p<0.00007)$, and GFR normalized to kidney weight was reduced in LP $(p<0.04)$. The number of
\end{abstract}

\section{ABSTRACT}

glomeruli per kidney was lower in adult LP offspring (21,567 \pm $1,694$, LP versus $28,917 \pm 2,342, \mathrm{NP}, p<0.03)$, and individual glomerular volume was higher $\left(1.81 \pm 0.1610^{6} \mu \mathrm{m}^{3}\right.$, LP versus $\left.1.11 \pm 0.1010^{6} \mu^{3}, \mathrm{NP}, p<0.005\right)$; the total volume of all glomeruli per kidney was not significantly different. Thus, perinatal protein restriction in the rat suppresses the newborn intrarenal RAS and leads to a reduced number of glomeruli, glomerular enlargement, and hypertension in the adult. (Pediatr Res 49: $460-467,2001$ )

Abbreviation
RAS, renin-angiotensin system
ERPF, effective renal plasma flow
NP, normal protein (19\%) diet
LP, low-protein (8.5\%) diet
ANGII, angiotensin II
PAH, para-amino hippurate

A decade ago, Barker et al. first reported an inverse relationship between birth weight and death from cardiovascular disease in adulthood (1). Subsequently, a number of epidemiologic studies in different parts of the world have found a relationship between early growth patterns and the risk of cardiovascular disease in adulthood (2-8). Although these

Received February 25, 2000; accepted November 10, 2000.

Correspondence and reprint requests: Lori L. Woods, Ph.D., Division of Nephrology, L463, Oregon Health Sciences University, 3181 S.W. Sam Jackson Park Rd., Portland, OR 97201-3098, U.S.A.; e-mail: woodsl@ohsu.edu

Supported by grant 1P01HD34430-01A1 from the National Institute of Child Health and Human Development (L.L.W.), grants HL48455 and HL40210 from the National Heart, Lung, and Blood Institute (J.R.I.), a Grant-in-Aid from the American Heart Association (L.L.W.), grants from the Danish Diabetes Association and NOVO (R.R.), and the Aarhus University Research Foundation (R.R.). findings remain somewhat controversial (9), the majority of evidence indicates that even within the "normal" range of birth weights, babies that are born smaller have a higher risk of death from cardiovascular disease when they reach adulthood. This indicates that some factor or factors in the perinatal environment, probably related at least in part to maternal nutrition, can "program" the individual for increased cardiovascular risk later in life. However, the precise physiologic and molecular mechanisms by which this programming occurs are unknown.

Recently, a rat model of perinatal protein restriction has been identified that has several features in common with the observations in humans, suggesting that this may be a good animal model of the human condition. In particular, offspring 
of rats that were protein-restricted during pregnancy have lower-than-normal birth weights and are hypertensive in adulthood (10). Thus, this model is useful for studying the mechanisms by which early growth patterns are related to adult cardiovascular disease.

Our overarching hypothesis is as follows. Maternal dietary protein restriction during pregnancy causes suppression of the fetal/newborn RAS. This leads to impaired renal development and a decreased number of nephrons at birth - a maldevelopment that persists into adulthood, leading in turn to hypertension and an increased risk for additional forms of cardiovascular disease. We have shown previously that pharmacologic suppression of the RAS in the developing animal leads to a reduced number of nephrons and hypertension in adulthood (11). We have also shown that a surgical reduction in the number of nephrons from birth leads to adult hypertension (12). The purpose of the present study was to determine whether perinatal suppression of the offspring RAS, and impaired nephron development, are present and thus could contribute to the programming for hypertension that occurs in offspring of protein-restricted mothers.

\section{METHODS}

Animals. All procedures on animals were approved by the Institutional Animal Care and Use Committee. Female Sprague Dawley rats (Simonsen, Gilroy, CA, U.S.A.) weighing approximately 250-300 g were bred at Oregon Health Sciences University and maintained on either a normal protein $(19 \%$ protein $=21 \%$ casein), normal sodium $(0.20 \%)$ diet (Purina basal diet 5755$)$ or a low-protein (8.5\%, LP), normal sodium diet (Purina diet 5769, modified from 5755) throughout pregnancy. Thus, protein restriction in these LP animals was moderate but not extreme. Although food was available ad libitum, we have found that intake of these synthetic diets is remarkably consistent at $19-20 \mathrm{~g} / \mathrm{d}$ in pregnant rats, independent of dietary content or litter size. Birth weights were measured on the first day of postnatal life, in the morning, no more than $15 \mathrm{~h}$ after delivery. (Rat dams generally deliver at night.) All dams were placed on the normal diet at delivery, and pups were weaned to the normal diet at $22 \mathrm{~d}$ of age and maintained on that diet until adulthood. The animals were housed in a room with a controlled temperature and a 12-h light/dark cycle. Some newborn animals were used for measurement of tissue renin mRNA, ANGII, and renin levels, or immunohistochemistry; litter mates were allowed to grow until adulthood for physiologic and morphometric measurements. To avoid possible gender differences, only male offspring were studied in all phases of the project.

Collection of newborn tissues. Newborn pups at 1 and $5 \mathrm{~d}$ of age were euthanized with commercial euthanasia solution (Euthasol, Delmarva Laboratories, Midlothian, VA, U.S.A.) given intraperitoneally. Care was taken to avoid injection into the kidneys. Kidneys were rapidly harvested, rinsed in saline, blotted, and snap-frozen in liquid nitrogen. They were kept frozen at $-70^{\circ} \mathrm{C}$ until measurements were performed.

Measurement of intrarenal RAS activity. For assessment of mRNA, total RNA was extracted from whole kidney tissues by the guanidium thiocyanate method of Chirgwin et al. (13) and quantitated by absorbance at $260 \mathrm{~nm}$ in duplicate, with RNA purity determined using $\mathrm{A}_{260} / \mathrm{A}_{280}$ ratios. Northern blots were run with $10 \mu \mathrm{g}$ total RNA/lane in formaldehyde gels. Following transblotting gels to nylon filters, and UV crosslinking, blots were hybridized to probes of choice. Full-length rat cDNA probes for angiotensinogen (14) and renin (15) were used. A rat angiotensin-converting enzyme (ACE) cDNA was used for studies of ACE mRNA (16). A glyceraldehyde-3phosphate dehydrogenase (GAPDH) cDNA was used as a housekeeping probe. Probes were labeled by random priming using ${ }^{32} \mathrm{P} 2$ '-deoxycytidine-5'-triphosphate (dCTP) to an activity of $1 \times 10^{8} \mathrm{dpm} / \mathrm{ng}$ DNA (17). Blots were prehybridized with Rapid-Hyb buffer (Amersham, Arlington Heights, IL, U.S.A.) for $1.5 \mathrm{~h}$ at room temperature, and hybridized for $1 \mathrm{~h}$ at $65^{\circ} \mathrm{C}$. Washing conditions included a prewash at room temperature $(2 \times \mathrm{SSC}, 0.1 \% \mathrm{SDS})$ and then washing twice at $65^{\circ} \mathrm{C}$ for $15 \mathrm{~min}$ in $0.1 \times \mathrm{SSC}$ with $0.1 \%$ SDS. Washed filters were exposed to Kodak XAR film bracketed by two intensifier screens. Each filter was then stripped according to the manufacturer's instructions and reprobed with a GAPDH probe. Relative amounts of mRNA were determined by scanning autoradiograms from Northern blots using a computer scanner and determining the mean density of the signals (Desk Scan II, version 1.5.1, Hewlett Packard, followed by Image, version 1.37, by Wayne Rasband, Research Services Branch, NIMH, Bethesda, MD, U.S.A.). Blots were normalized with signals from GAPDH, scanned in the same manner. Data are expressed as mRNA level (relative densitometric units normalized to GAPDH).

To measure renal tissue ANGII levels, the kidneys from 1-d-old newborn rat pups ( $n=3$ per group) were rapidly harvested as described above, rinsed in ice-cold inhibitor solution (125 mmol/L Na ${ }_{4}$ EDTA (Sigma Chemical Co.), 1 $\mathrm{mmol} / \mathrm{L}$ enalaprilat (Merck), $25 \mathrm{mmol} / \mathrm{L}$ phenanthroline (Sigma Chemical Co., Rahway, NJ, U.S.A.), and $1 \mathrm{mmol} / \mathrm{L}$ pepstatin A (Sigma Chemical Co.) in 2\% ethanol), and snap frozen in liquid nitrogen. Tissue was homogenized in cold $8 \mathrm{mmol} / \mathrm{L}$ urea, $0.1 \%$ Triton $\mathrm{X}-100$ and $90 \%$ methanol, $10 \mathrm{mmol} / \mathrm{L}$ sodium acetate, $0.1 \%$ trifluoroacetic acid (TFA) in a Dounce homogenizer. Samples were centrifuged at $30,000 \mathrm{rpm}$ $(913,000 \mathrm{~g})$ for $10 \mathrm{~min}$ at $4^{\circ} \mathrm{C}$. The supernatant was filtered through a Sep-Pak column (Waters, Millis, MA, U.S.A.), and then peptides were eluted in $80 \%$ methanol and $0.1 \%$ TFA and lyophilized. Recovery of ANGII standard (Sigma Chemical Co.) over a range of $10-200 \mathrm{fmol} / \mathrm{mL}$ by this procedure was 95\%. An ANGII RIA was then performed using a commercial rabbit anti-ANGII antibody (Arnel, NY, U.S.A.) and a donkey anti-rabbit second antibody (Amersham, Arlington Heights, IL, U.S.A.) for magnetic separation of bound and unbound tracer $(18,19)$.

For assessment of renin immunohistochemistry, kidneys from 1-d-old newborn rat pups were fixed in $4 \%$ paraformaldehyde, dehydrated, and then embedded in paraffin blocks. Five-micrometer sections were immunostained for renin by the immunoperoxidase technique using diaminobenzidine tetrahydrochloride as the chromogen (20). Sections were then counterstained with Gill's triple-strength hematoxylin (Fisher Sci- 
entific, Fair Lawn, NJ, U.S.A.). The primary antibody was a polyclonal rabbit anti-rat renin antibody $(1: 1000)$ kindly provided by Dr. Tadashi Inagami of Vanderbilt University (21), and the secondary antibody was a goat anti-rabbit antibody (Vector Laboratories, Burlingame, CA, U.S.A.).

To measure renal tissue renin activity, the kidneys from 1-d-old newborn rat pups ( $n=4$ per group) were rapidly harvested and snap frozen as described above. They were homogenized in $0.1 \mathrm{M}$ Tris, $\mathrm{pH} 7.4$ to which EDTA (final concentration $4 \mathrm{mM})$, sodium tetrathionate $(5 \mathrm{mM})$, phenylmethylsulfonyl fluoride $(0.1 \mathrm{mM})$, and Triton X-100 were added. The tissue homogenate was incubated for $1 \mathrm{~h}$ at $37^{\circ} \mathrm{C}$, following the addition of exogenous excess substrate (anephric plasma from rats), $\mathrm{pH} 7.4$ with additional protease inhibitors (3.4 mM 8-hydroxyquinolone sulfate and $1.6 \mathrm{mM}$ dimercaprol). The angiotensin I generated was measured by RIA (22). Data were normalized by protein content (BioRad, Burlingame, CA, U.S.A.) (23).

Surgical preparation of adult animals. At approximately 20 wk of age, nine LP and nine NP adult male animals were chronically instrumented for measurements of arterial pressure and renal function. Briefly, they were anesthetized with a mixture of $55 \%$ ketamine $(100 \mathrm{mg} / \mathrm{mL}), 28 \%$ xylazine $(20$ $\mathrm{mg} / \mathrm{mL}), 11 \%$ acepromazine $(10 \mathrm{mg} / \mathrm{mL})$, and $6 \%$ sterile water, administered at $1.0 \mathrm{~mL} / \mathrm{kg}$ intraperitoneally. The sites of the incisions were shaved and swabbed with betadine, and all catheters, suture, instruments, and gloves used were sterile. Through a midline abdominal incision, a stainless steel silasticcovered catheter was inserted through a puncture hole at the apex of the bladder and secured by a pursestring suture. The muscle was sutured closed around the catheter, which exited through the skin on the ventral surface of the abdomen. The bladder was flushed with chloramphenicol sodium succinate (30 mg/mL), and the catheter was plugged with a stainless steel pin covered with silastic tubing. Sterile catheters made of Tygon microbore tubing were implanted into the left femoral artery and vein and tunneled under the skin to exit on top of the head, where they were secured. The catheters were filled with heparin $(500 \mathrm{U} / \mathrm{mL})$ following surgery, and plugged with stainless steel wire pins. For the first $24 \mathrm{~h}$ after surgery, a mixture of rat chow and 5\% dextrose was provided in a bowl to encourage eating. Animals were allowed to recover in individual cages for at least $7 \mathrm{~d}$ before any experiments were conducted, and were maintained on the normal protein, normal sodium diet. The bladder catheter was flushed on the first day after surgery with chloramphenicol. Vascular catheters were flushed every 2 or $3 \mathrm{~d}$ to maintain patency. During the recovery period, the animals were placed in a wire restrainer in the study room for at least $2 \mathrm{~h}$ on at least three occasions to allow them to become acclimatized to the study conditions. The animals were noticeably more calm after several training sessions, frequently falling asleep during the experiments. However, it remains possible that some of the differences between groups could have reflected differences in response to restraint.

Physiologic studies in adult offspring. The animals were $21.0 \pm 0.4 \mathrm{wk}$ of age at the time of study. To make physiologic measurements, the rat was placed in a wire restrainer in the study room. Urine was allowed to drain continuously from the bladder catheter into a tube throughout the experiment. Mean arterial pressure was measured through the arterial catheter using a pressure transducer (Statham, Oxnard, CA, U.S.A.) connected to a polygraph (Grass Instruments, Quincy, MA, U.S.A.), and a reading was taken after at least $30 \mathrm{~min}$, once the pressure had stabilized. Arterial pressures were always measured between 0600 and $0900 \mathrm{~h}$. After the pressure measurement, a blood sample $(0.5 \mathrm{~mL})$ was taken from the arterial catheter. Microhematocrit and plasma protein were measured, and the remainder was placed on ice in a tube containing sodium EDTA, centrifuged at $4^{\circ} \mathrm{C}$, and the plasma was frozen at $-20^{\circ} \mathrm{C}$ until analysis for plasma renin activity. Inulin (Sigma Chemical Co.) and PAH (Sigma Chemical Co.) in 5\% dextrose were given i.v. as a bolus $(0.45 \mathrm{~mL}$ containing $56 \mathrm{mg}$ inulin and $5.6 \mathrm{mg} \mathrm{PAH}$ ) followed by a continuous infusion (0.024 $\mathrm{mL} / \mathrm{min}$ of $74 \mathrm{mg} / \mathrm{mL}$ inulin and $7.4 \mathrm{mg} / \mathrm{mL} \mathrm{PAH})$ throughout the rest of the experiment. At least $60 \mathrm{~min}$ after beginning the inulin/PAH infusion, urine was collected in a series of three or four successive 20 -min clearance periods, with a blood sample $(0.5 \mathrm{~mL})$ taken at the midpoint of each. Blood was collected in sterile heparinized syringes. Urine volume was determined gravimetrically. After centrifuging the blood and removing the plasma, the red cells were resuspended in an equivalent volume of saline and returned to the animal. The plasma was frozen at $-20^{\circ} \mathrm{C}$ for later analysis.

Stereology and histopathology. When all experiments were completed or when the instrumentation was no longer functional, the rats were killed with a commercial euthanasia solution (Euthasol). The left kidney was fixed in 2\% paraformaldehyde, $2.5 \%$ glutaraldehyde in $0.1 \mathrm{M}$ phosphate. The number of glomeruli was estimated by the disector technique (24). Briefly, this technique consists of a three-dimensional counting rule using pairs of parallel section planes separated by a known distance, $h$. The glomeruli are counted if they are present in an unbiased counting frame on one plane (the reference plane) but not on its partner (the look-up plane). The disector alone generates number of glomeruli per volume kidney tissue (number density). In consequence, the number density is multiplied with the total volume of the kidney (reference volume) to obtain the total number of glomeruli. Specifically, the fixed kidney was cut in 2-mm thick horizontal slices and approximately five slices were systematic, uniformly random sampled $(25,26)$. The first slice to be sampled was randomly chosen to be either 1 or 2 . Then the slices were sampled with a sampling periodicity of two: e.g. 1, 3, 5, 7, etc. The sampled sections were embedded in Technovit (Heracus Kulzer GMBH, Wehrheim, Germany). From the approximate center of each tissue slice, three $15-\mu \mathrm{m}$ thick sections were cut on a Leica RM 2165 vibratome and stained with PAS and hematoxylin. The first and third sections were used for glomerular number estimation. The glomeruli disappearing from the first section to the third section and vice vera were counted, $\Sigma \mathrm{Q}^{-}$(25), using an Olympus BH-2 microscope connected to a monitor by the use of a CCD video camera (Sony VCC 400P). The total number of glomeruli, N(glo), in a kidney was estimated as:

$$
\mathrm{N}(\text { glo })=\left[\sum \mathrm{Q}^{-} /\left(2 * \mathrm{~h} * \sum \mathrm{a}\right)\right] * \mathrm{KW}
$$


where $\mathrm{h}$ is the height of the disector $(30 \mu \mathrm{m}), \Sigma \mathrm{a}$ is the total area of the kidney on sampled sections, and KW is the kidney weight converted to a kidney volume $\left(1 \mathrm{~g} \sim 1 \mathrm{~cm}^{3}\right)$. The sampling variance or coefficient of error of this stereologic technique was estimated to be $5.2 \%$. The average volume of individual glomeruli, $\overline{\mathrm{v}}(\mathrm{glo})$, was estimated by

$$
\overline{\mathrm{v}}(\mathrm{glo})=\mathrm{V}_{\mathrm{v}}(\text { glo } / \mathrm{kid}) \times \mathrm{KW} / \mathrm{N}(\mathrm{glo})
$$

where $\mathrm{V}_{\mathrm{V}}$ (glo/kid) is the volume density of glomeruli in the kidney, estimated by point counting.

The right kidney was fixed in $10 \%$ phosphate-buffered formalin for a minimum of $48 \mathrm{~h}$. Transverse sections through the central portion of each kidney were processed through graded alcohols and xylenes, and then embedded in paraffin. Sections $(5 \mu \mathrm{m})$ were stained with hematoxylin and eosin, periodic acid-Schiff (with prior diastase treatment), or silver and examined on a Leica DMLB microscope for evaluation of renal pathology.

Analytical measurements. Inulin in plasma and urine was assayed by a modification of the method of Waugh (27) after deproteinization with zinc sulfate. PAH was assayed on the same samples using the method of Brun (28). GFR was calculated as the renal clearance of inulin $\left[\mathrm{GFR}=\left(\mathrm{U}_{\mathrm{in}} / \mathrm{P}_{\mathrm{in}}\right) \times\right.$ $V]$, where $U_{\text {in }}$ and $P_{\text {in }}$ are the urine and arterial plasma inulin concentrations respectively, and $\mathrm{V}$ is the urine flow rate. ERPF was calculated as the renal clearance of PAH. The values obtained for the three or four clearance periods were averaged to give a single value for each animal. Plasma protein was measured by refractometry (National Instrument, Baltimore, MD, U.S.A.). Plasma renin activity was measured by RIA using a kit from New England Nuclear.

Statistical analysis. The data are expressed as means \pm SE. Data for the two groups were compared using an unpaired $t$ test. Statistical significance was assumed with a value of $p<$ 0.05 or better. Tissue renin mRNA levels in the neonatal period were compared by two-way (diet $\times$ age) ANOVA.

\section{RESULTS}

Effects of maternal protein restriction on the newborn intrarenal RAS. Figure $1 A$ depicts a representative Northern blot for renin mRNA. The kidneys of pups from LP mothers demonstrated decreased expression of renin compared with those of pups from NP mothers. Figure $1 B$ shows these data graphically. The down-regulation of renal renin mRNA expression was sustained at least through $\mathrm{d} 5$ of postnatal age. There were no significant differences in renal angiotensinogen or ACE mRNA levels (data not shown).

Representative renin immunostaining in kidneys of 1-d-old offspring of mothers on normal and protein-restricted diets during pregnancy is shown in Fig. 2. Immunostaining is visible in the afferent arteriole of the normal pup (upper panel), whereas the kidney of the LP pup has virtually no renin immunostaining evident (lower panel). Renal tissue renin concentration was also reduced in LP pups $(0.94 \pm 0.05 \mathrm{ng}$ $\mathrm{AI} / \mathrm{mg} / \mathrm{h}, \mathrm{LP}$ versus $1.34 \pm 0.07 \mathrm{ng} \mathrm{AI} / \mathrm{mg} / \mathrm{h}, \mathrm{NP}, p<0.005)$.

Renal tissue ANGII levels were also significantly reduced in 1-d-old newborn offspring of protein-restricted mothers com-
A

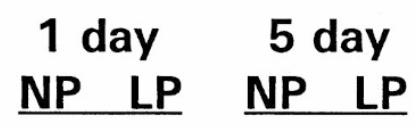

Renin
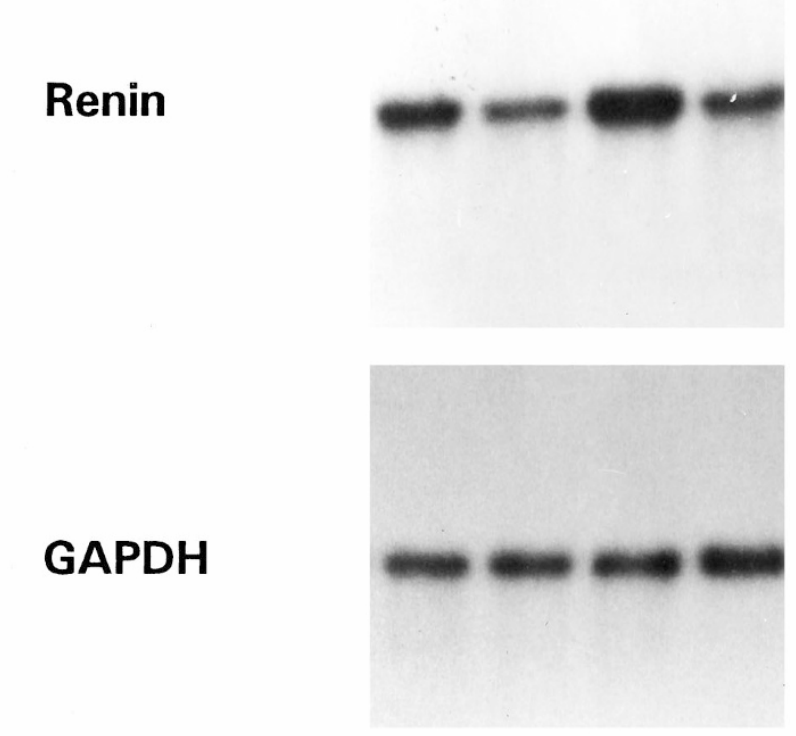

B

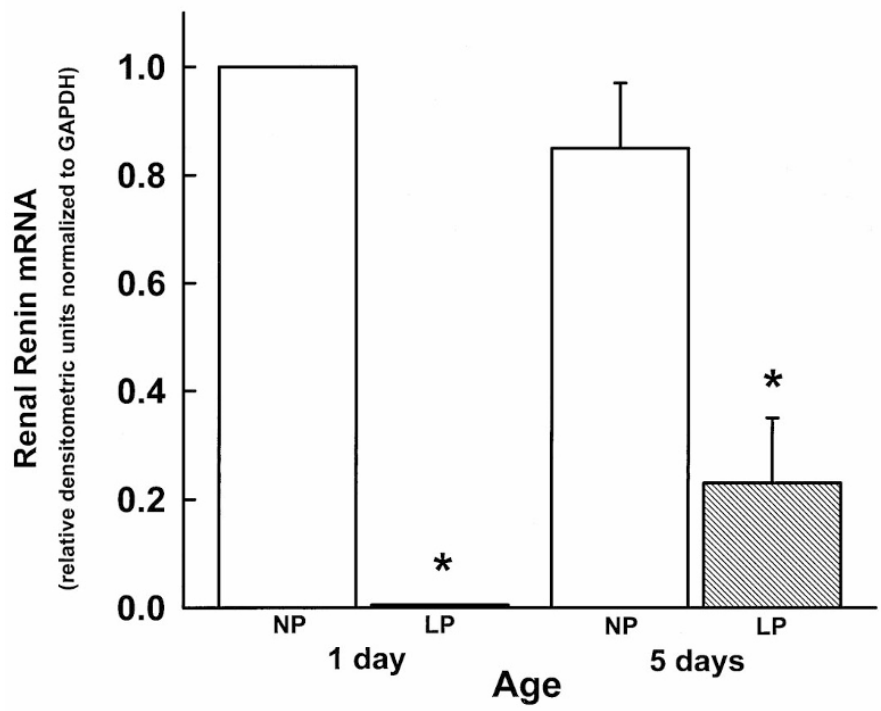

Figure 1. Renal renin mRNA in 1- and 5-d-old rat offspring of mothers maintained on NP $(19 \%)$ or LP $(8.5 \%)$ diets during pregnancy. $(A)$ Representative Northern blot, $10 \mu \mathrm{g}$ total RNA/lane. Blot was hybridized with a full-length rat renin cDNA probe and with a GAPDH probe. (B) Relative densitometric values normalized to GAPDH. Solid bars, NP diet; shaded bars, LP maternal diet. Mean \pm SE. $n=7$ per group, $* p<0.05$ compared with control.

pared with controls $(0.079 \pm 0.002 \mathrm{ng} / \mathrm{mg}$ tissue, LP versus $0.146 \pm 0.016 \mathrm{ng} / \mathrm{mg}$ tissue, NP, $p<0.01$ ).

Effects of maternal protein restriction on growth in the offspring. Birth weights were significantly lower in offspring of protein-restricted mothers $(5.49 \pm 0.20 \mathrm{~g}$, LP versus $6.34 \pm$ $0.07 \mathrm{~g}, \mathrm{NP}, p<0.00005, n=21$ LP litters and 29 NP litters), although the number of pups per litter was not different (10 \pm 1 , LP versus $11 \pm 1, \mathrm{NP}$ ). The kidney-to-body weight ratio at 


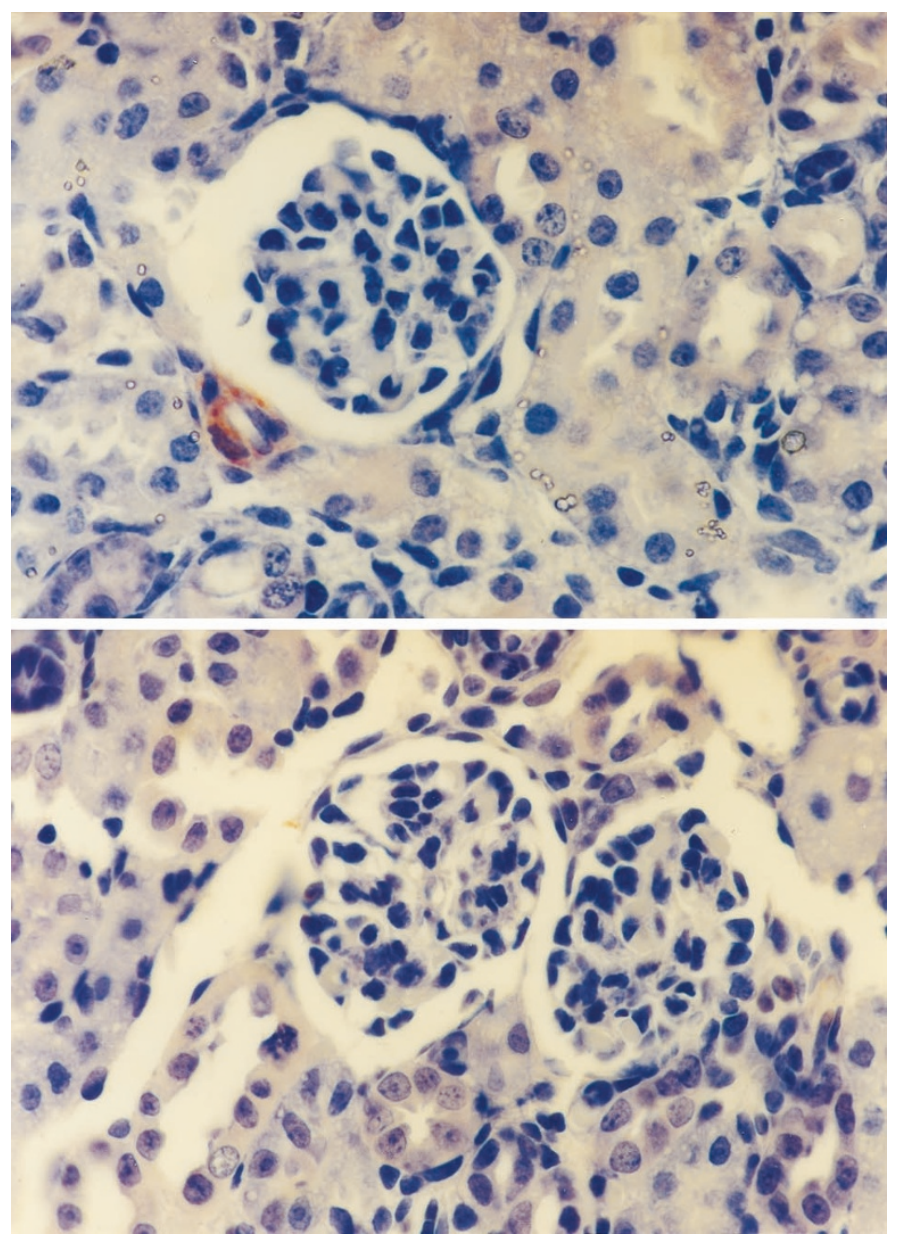

Figure 2. Top: Renal cortex of a 1-d-old newborn rat whose mother was on a NP (19\%) diet during pregnancy. Renin immunostaining is seen in the afferent arteriole (original magnification $\times 300$ ). Bottom: Renal cortex of a 1-d-old newborn rat whose mother was on a LP $(8.5 \%)$ diet during pregnancy. Virtually no immunostaining is evident in the kidney after perinatal protein restriction (original magnification $\times 300$ ).

birth was reduced from $0.970 \pm 0.033 \%$ (NP) to $0.760 \pm$ $0.014 \%(\mathrm{LP})(p<0.0003)$, indicating specific impairment of fetal renal growth. Body weights at weaning were not significantly different in the two groups $(70 \pm 4 \mathrm{~g}$, LP versus $69 \pm$ $3 \mathrm{~g}, \mathrm{NP}$ ). Adult body weights at the time of study were also not different $(435 \pm 17 \mathrm{~g}$, LP versus $445 \pm 22 \mathrm{~g}$, NP). In adult animals, total kidney weight $(3.19 \pm 0.17 \mathrm{~g}$, LP versus $2.85 \pm$ $0.20 \mathrm{~g}, \mathrm{NP})$ and the kidney-to-body weight ratio $(0.697 \pm$ $0.017 \%$, LP versus $0.658 \pm 0.019 \%$, NP) were not significantly different.

Effects of maternal protein restriction on physiologic variables in the offspring. Hematocrits were higher in offspring of protein-restricted mothers ( $46 \pm 1 \%$, LP versus $41 \pm 1 \%$, NP, $p<0.02$ ), but plasma protein levels were not significantly different $(6.7 \pm 0.1 \mathrm{~g} / \mathrm{dL}$, LP versus $6.5 \pm 0.1 \mathrm{~g} / \mathrm{dL}, \mathrm{NP})$. Arterial pressures and renal hemodynamics in adult offspring of rats fed normal or protein-restricted diets during pregnancy are shown in Figure 3. Mean arterial pressure was significantly increased by an average of $10 \mathrm{~mm} \mathrm{Hg}$ in offspring of proteinrestricted mothers compared with controls $(p<0.00007)$. Absolute GFR tended to be reduced (by an average of $11 \%$ ),
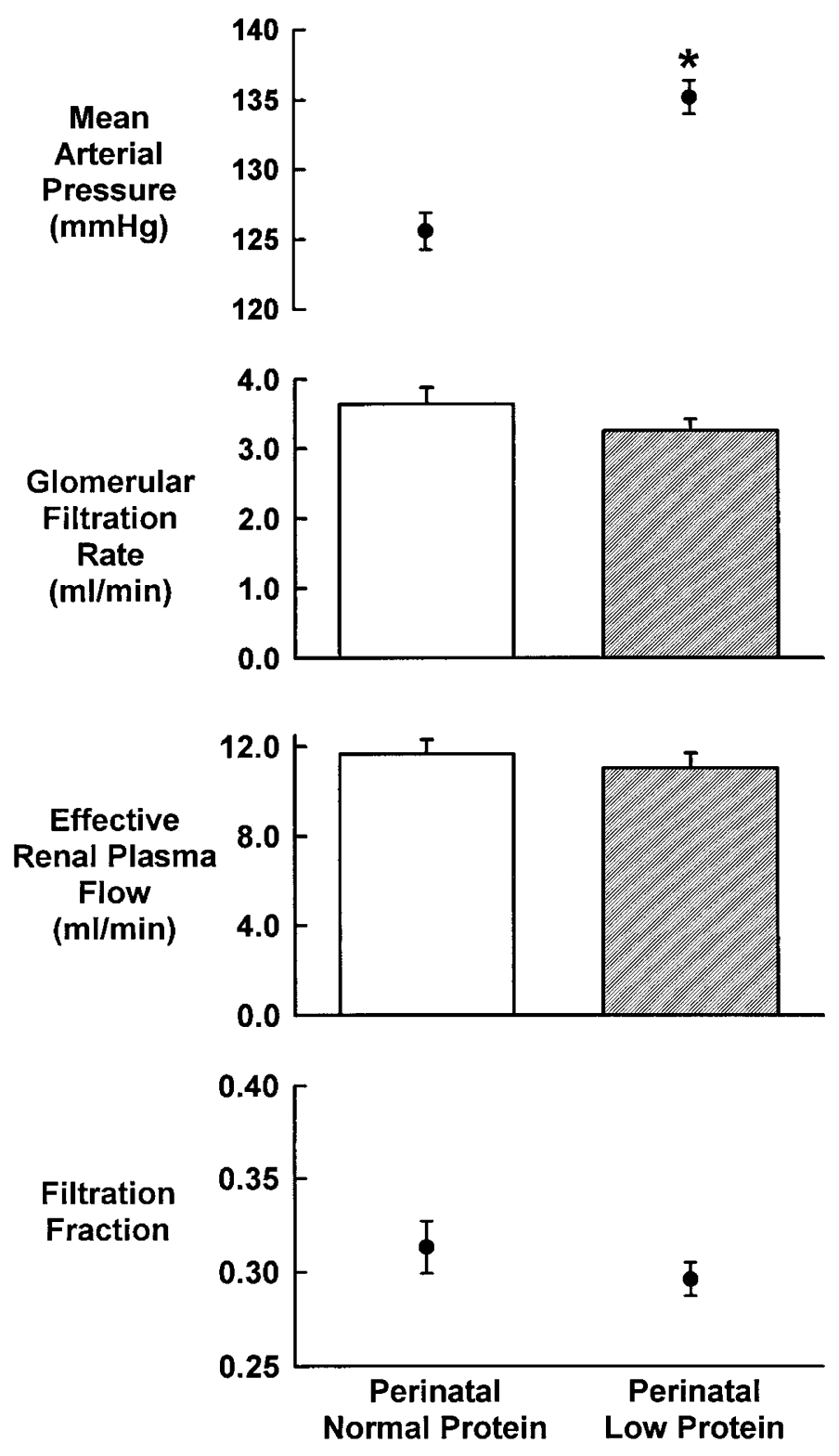

Figure 3. Arterial pressure and renal hemodynamics in adult male rats exposed prenatally to NP (19\%) and LP $(8.5 \%)$ maternal diets. Mean \pm SE, $n$ $=9$ per group. ${ }^{*} p<0.05$ compared with control.

although this did not reach statistical significance, and ERPF was also not significantly different. However, the GFR normalized to kidney weight was significantly reduced in LP (1.09 \pm $0.08 \mathrm{~mL} / \mathrm{min} / \mathrm{g}$, LP versus $1.29 \pm 0.04 \mathrm{~mL} / \mathrm{min} / \mathrm{g}$, NP, $p<$ $0.04)$. The mean filtration fraction was not different. Plasma renin activity was not significantly different between the two groups $(6.1 \pm 0.9 \mathrm{ng} \mathrm{ANGI} / \mathrm{mL} / \mathrm{h}$, LP versus $6.6 \pm 1.4 \mathrm{ng}$ $\mathrm{ANGI} / \mathrm{mL} / \mathrm{h}, \mathrm{NP})$.

Effects of maternal protein restriction on renal structure in offspring. The total number of glomeruli and glomerular volume are shown in Figure 4. Total glomerular number was significantly reduced by $25 \%$ in adult offspring of proteinrestricted mothers $(21,567 \pm 1,694$, LP versus $28,917 \pm 2,342$, NP, $p<0.03$ ), and the average glomerular volume was increased $\left(1.81 \pm 0.1610^{6} \mu \mathrm{m}^{3}\right.$, LP versus $1.11 \pm 0.1010^{6}$ $\mu \mathrm{m}^{3}$, NP, $p<0.005$ ), such that the total volume of all glomeruli per kidney was not significantly different. 

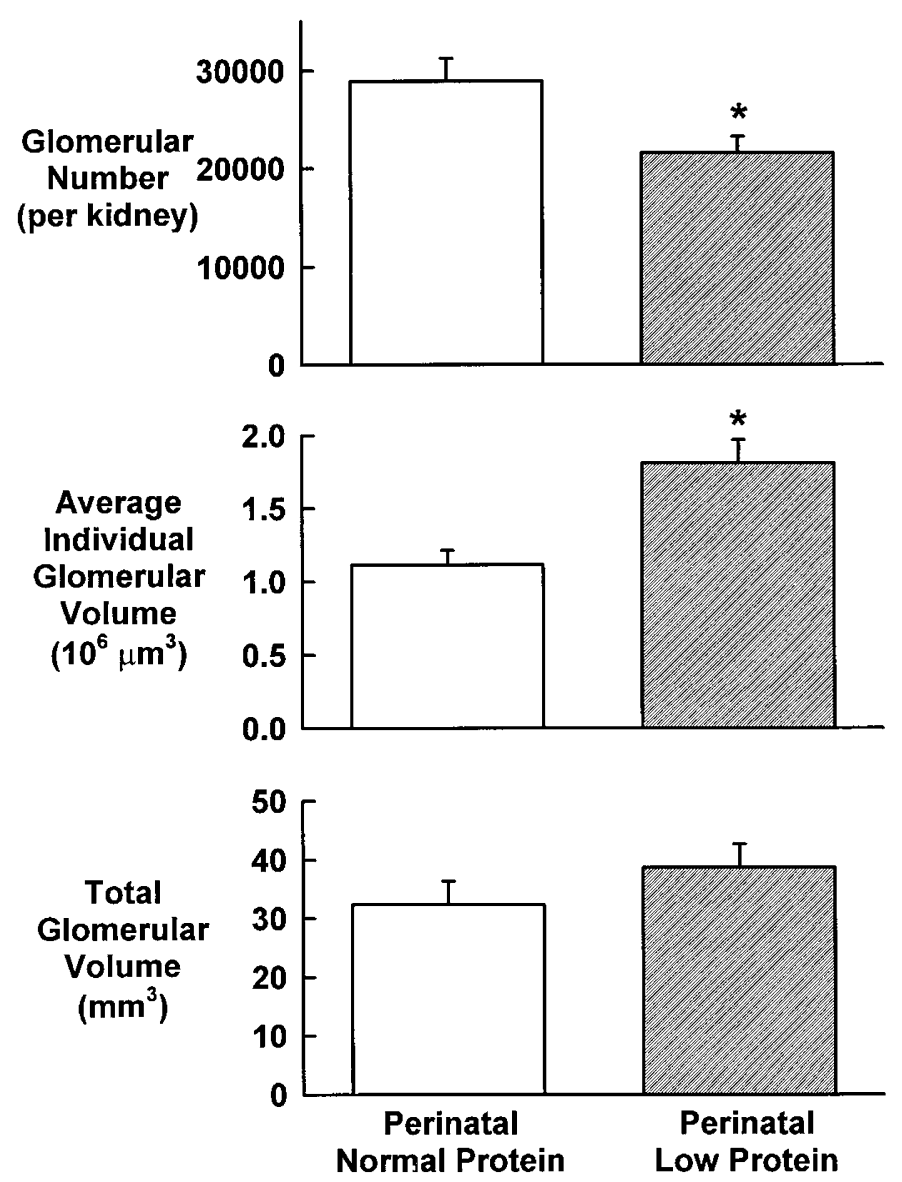

Figure 4. Glomerular number and volume in adult male rats exposed prenatally to NP $(19 \%)$ and LP $(8.5 \%)$ maternal diets. Mean \pm SE, $n=6$ per group. ${ }^{*} p<0.05$ compared with control.

Sections of the formalin-fixed, paraffin-embedded kidneys were examined in detail to determine whether there were differences in pathology between the two treatment groups at the light microscope level. Evidence of tubular atrophy, cyst formation, interstitial inflammation, and fibrosis was present in small, patchy areas in the kidneys from both groups without a difference in frequency. There was no significant glomerulosclerosis or arteriosclerosis in either group.

\section{DISCUSSION}

This study shows that moderate maternal dietary protein restriction during pregnancy results in reduced birth weight and suppression of the newborn intrarenal RAS, followed by a decreased number of glomeruli, decreased renal function (GFR/kidney weight), and increased arterial pressure in adulthood. These findings support a possible mechanism by which the perinatal environment could "program" the individual for increased cardiovascular risk later in life.

We have hypothesized that factors in the perinatal environment that suppress the RAS in the developing fetus/newborn lead to impaired renal development and fewer nephrons at birth, in turn leading to adult hypertension. This could provide a mechanistic link between maternal environmental factors, particularly dietary factors, and the development of hypertension and related cardiovascular diseases in adulthood (11). To substantiate this hypothesis, two goals must be accomplished: 1) it must be shown that all of these factors are present in a single physiologic model, and 2) a cause-and-effect relationship must be established among the various factors.

The present work addresses the first of these two goals. In offspring of protein-restricted mothers, we found that intrarenal renin mRNA, renin concentration, and immunostaining for renin are decreased during a critical period in nephron development. The ultimate result appears to be reduced intrarenal ANGII levels during nephrogenesis, which would lead to aberrant renal development in LP animals. In considering the potential roles of the RAS in these models of hypertension, it is important to distinguish between RAS activity in adulthood and that during the critical window of development in which nephrogenesis occurs (from approximately mid-gestation to about $10 \mathrm{~d}$ after birth in the rat (29)). It is likely that the RAS plays two essentially separate roles in mediating the hypertension, one during the developmental period in setting the total nephron endowment, and a second during adult life in regulating the blood pressure around its preprogrammed set point. It is also important to distinguish between the circulating and intrarenal RAS, which do not necessarily change in parallel. It is the intrarenal RAS that is thought to be most important in causing structural changes involved in long-term physiologic regulation. Consistent with our findings in adult offspring in the present study, others have reported no significant differences in the circulating RAS in adult offspring of modestly proteinrestricted mothers compared with controls (30). Offspring of rats that were protein restricted throughout pregnancy have normal plasma renin activities (PRAs) but reduced plasma ANGII levels at 4 wk of age (31). Although this is beyond the window of nephrogenesis, it does suggest that the circulating RAS may be suppressed in early life in these animals. However, the present study is the first to examine the intrarenal RAS in the immediate postnatal period in this model. We found suppression of renal renin mRNA and renin concentrations as well as renin immunostaining, and reduced tissue ANGII levels during this critical developmental window, thus supporting our overarching hypothesis. Further support is provided by the recent finding that the intrarenal RAS is also suppressed in fetal sheep with placental insufficiency, another model of intrauterine malnutrition (32).

Using unbiased techniques, we also found that the number of nephrons in the offspring was reduced in this rat model of maternal protein restriction. This finding is in general agreement with results of previous studies in which maternal intake was more severely restricted and which used less reliable techniques to estimate glomerular number (33-35). The importance of using unbiased, stereologic techniques in renal research has recently come to the forefront (36). We show here that even modest maternal protein restriction causes a $25 \%$ decrease in the number of nephrons in the offspring.

We also found that modest maternal protein restriction to $8.5 \%$ protein ( $9 \%$ casein) throughout gestation resulted in adult male offspring with a conscious, resting mean arterial blood pressure that is $\sim 10 \mathrm{~mm} \mathrm{Hg}$ higher than controls. In support of this finding, lambs born to sheep that were nutrient-restricted early in pregnancy have elevated blood pressures (37). Langley 
and Jackson (10) have reported that female offspring of rats that were protein-restricted (either $6 \%$ or $9 \%$ casein) during pregnancy have an increased systolic blood pressure at 9 wk of age (22 $\mathrm{mm} \mathrm{Hg}$ and $16 \mathrm{~mm} \mathrm{Hg}$, respectively) that was still significantly increased at $21 \mathrm{wk}$. In contrast, Holemans et al. (38) have recently found no hypertension in adult female offspring of rats that were food restricted during the second half of pregnancy. Thus, the effects of modest or severe maternal food or protein restriction on offspring blood pressure remain somewhat controversial. Nevertheless, our present work shows that a reduced number of glomeruli and hypertension co-exist in the same animal model, one in which maternal protein intake in pregnancy was only modestly restricted, and in which the intrarenal RAS was shown to be suppressed during development. Thus, the results of the present study demonstrate that all of the necessary factors that play a role in our overarching hypothesis (newborn RAS suppression, reduced number of nephrons, and adult hypertension) are present together in this physiologic model.

Our previous work and that of others have addressed the second of the above goals, that of establishing a cause-andeffect relationship among the above factors. A variety of recent studies using gene targeting (39-42) and pharmacological approaches (43-46) have demonstrated the importance of the RAS for normal renal development. We have recently extended these findings to show that pharmacologic blockade of the RAS during the developmental period has long-term effects on physiologic regulation of arterial pressure and renal function (11). Specifically, we found that blockade of the ANGII $\mathrm{AT}_{1}$ receptor during the first $12 \mathrm{~d}$ of postnatal life resulted in a reduced number of glomeruli, reduced renal function, and increased arterial pressure in adult animals (11). Importantly, the period of RAS blockade we used in those studies corresponded closely to that in which suppression of the intrarenal RAS was seen in the present work. Furthermore, the magnitudes of the differences in glomerular number, GFR, and arterial pressure were also comparable to those seen in the present study in which the neonatal RAS was physiologically suppressed. Thus, the perinatal RAS plays a critical role in long-term physiologic regulation. Moreover, the timing of physiologic RAS suppression in this present model of protein restriction would appear to be sufficient to account for the subsequent derangements in renal structure and function, and arterial pressure that occur.

To lend further support to our overarching hypothesis, it is also important to establish a cause-and-effect relationship between a reduced nephron endowment from birth and adult hypertension, a relationship that has been proposed by Brenner and colleagues (47). To address this question specifically, we uninephrectomized rat pups within the first $24 \mathrm{~h}$ of postnatal life (12). This degree of reduction in nephron number from birth caused a clear increase in mean arterial pressure in adulthood, similar to that seen in the perinatally proteinrestricted animals in the present studies. Thus, we have also previously established a cause-and-effect relationship between a reduced number of nephrons from birth and adult hypertension.
In the present study, GFR tended to be reduced in offspring of protein-restricted mothers, although the difference was statistically significant only when normalized for kidney weight. This probably represents a true decrease in GFR, one that is physiologically significant but too small to be detected given interanimal variability and the sensitivity of methods for measuring GFR. This average fall in GFR of $11 \%$, coupled with the average reduction in glomerular number of $25 \%$, suggests that the remaining nephrons have increased their individual GFR by $\sim 20 \%$. Both the increased glomerular volume and the increased GFR per nephron in offspring of protein-restricted mothers are consistent with the well-known structural and functional responses to a reduction in total number of nephrons. These responses may, over the long term, contribute to hypertension and the progression of renal disease $(48,49)$.

Other investigators have hypothesized a role for glucocorticoids in programming for offspring hypertension, based on several pharmacologic studies $(50-53)$. The fetus is normally protected from the effects of maternal glucocorticoids by a placental enzyme, $11 \beta$ hydroxysteroid dehydrogenase (11 $\beta$ HSD), which inactivates them before they reach the fetus. The activity of this enzyme is reduced in placentas of proteinrestricted rats (54), and it is thought by some that this reduced activity of $11 \beta \mathrm{HSD}$ in protein-restricted mothers allows exposure of the fetus to maternal glucocorticoids, which in turn program the fetus for hypertension. The relationship between increased exposure to maternal glucocorticoids and suppression of the fetal/newborn intrarenal RAS in programming for offspring hypertension is not clear. However, reported interactions among glucocorticoids, the intrarenal RAS, and nephrogenesis $(55,56)$ suggest that maternal glucocorticoids could provide a signal for suppression of the intrarenal RAS in the present rat model. Further studies are needed to examine this possibility.

In summary, the present study shows that in a single physiologic model, modest maternal dietary protein restriction causes suppression of the intrarenal RAS in the developing offspring, as well as a reduced number of nephrons and hypertension in adulthood. Taken together with our previous findings, these new data provide strong evidence that alterations in the RAS and a resulting impairment of renal development provide a mechanism by which the perinatal environment programs the individual for deranged physiologic function, and in particular hypertension, later in life.

Acknowledgments. The authors thank Nabiel Azar, Sharon Cheney, Birgitte Grann, Chao-Yu Hsu, and Stephen Shih for technical assistance, and Dr. Christopher Corless for evaluation of renal pathology.

\section{REFERENCES}

1. Barker DJP, Winter PD, Osmond C, Margetts B, Simmonds SJ 1989 Weight in infancy and death from ischaemic heart disease. Lancet 2:577-580

2. Barker DJP, Bull AR, Osmond C, Simmonds SJ 1990 Fetal and placental size and risk of hypertension in adult life. BMJ 301:259-262

3. Barker DJP, Osmond C, Simmonds SJ, Wield GA 1993 The relation of head size and thinness at birth to death from cardiovascular disease in adult life. BMJ 306:422-426

4. Rich-Edwards JW, Stampfer MJ, Manson JE, Rosner B, Hankinson SE, Colditz GA, Willett WC, Hennekens CH 1997 Birth weight and risk of cardiovascular disease in a cohort of women followed up since 1976. BMJ 315:396-400 
5. Stein CE, Fall CHD, Kumaran K, Osmond C, Cox V, Barker DJP 1996 Fetal growth and coronary heart disease in South India. Lancet 348:1269-1273

6. Forsen T, Eriksson JG, Tuomilehto J, Teramo K, Osmond C, Barker DJP 1997 Mother's weight in pregnancy and coronary heart disease in a cohort of Finnish men follow up study. BMJ 315:837-840

7. Leon DA, Koupilova I, Lithell HO, Berglund L, Mohsen R, Vagero D, Lithell UB, McKeigue PM 1996 Failure to realise growth potential in utero and adult obesity in relation to blood pressure in 50 year old Swedish men. BMJ 312:401-406

8. Moore VM, Cockington RA, Ryan P, Robinson JS 1999 The relationship between birth weight and blood pressure amplifies from childhood to adulthood. J Hypertens $17: 883-888$

9. Jones SE, Nyengaard JR 1998 Low birth weight and cardiovascular disease: myth or reality? Curr Opin Lipidol 9:309-312

10. Langley SC, Jackson AA 1994 Increased systolic blood pressure in adult rats induced by fetal exposure to maternal low protein diets. Clin Sci 86:217-222

11. Woods LL, Rasch R 1998 Perinatal ANGII programs adult blood pressure, glomerular number, and renal function in rats. Am J Physiol 275:R1593-R1599

12. Woods LL 1999 Neonatal uninephrectomy causes hypertension in adult rats. Am J Physiol 276:R974-R978

13. Chirgwin JM, Pryzbyla AE, MacDonald RJ, Rutter WJ 1979 Isolation of biologically active ribonucleic acid from sources enriched in nuclease. Biochemistry 18:52945299

14. Lynch KR, Simnad VT, Ben-Ari ET, Garrison JC 1986 Localization of preangiotensinogen messenger RNA sequences in the rat brain. Hypertension 8:540-543

15. Burham CE, Hawelu-Johnson CL, Frank BM, Lynch KR 1987 Molecular cloning of rat renin cDNA and its gene. Proc Natl Acad Sci U S A 84:5605-5609

16. Koike F, Krieger JE, Jacob HJ, Mukoyama M, Pratt RE, Dzau VJ 1994 Angiotensin converting enzyme and genetic hypertension: cloning of rat cDNAs and characterization of the enzyme. Biochem Biophys Res Commun 198:380-386

17. Feinberg A, Vogelstein B 1983 A technique for radiolabeling DNA restriction endonuclease fragments to high specific activity. Anal Biochem 132:6-13

18. Kifor I, Dzau VJ 1986 Endothelial renin-angiotensin pathway: evidence for intracellular synthesis and secretion of angiotensins. Circ Res 60:422-428

19. Reams G, Villarreal D, Wu Z, Bauer JH 1993 Renal tissue angiotensin II: response to infusions of angiotensin I and an angiotensin-converting enzyme inhibitor. Am J Kidney Dis 22:851-857

20. Ralini B, Taylor CR 1983 New developments in immunoperoxidase technique and their application. Arch Path Lab Med 107:105-115

21. Naruse K, Takii Y, Inagami T 1981 Immunohistochemical localization of renin in luteinizing hormone-producing cells of rat pituitary. Proc Natl Acad Sci U S A 78:7579-7583

22. Haber E, Koerner T, Page LB, Kliman B, Purnode A 1969 Application of radioimmunoassay for angiotensin I to physiologic measurement of plasma renin activity in normal human subject. J Clin Endocrinol Metab 29:1349-1355

23. Bradford MM 1976 A rapid and sensitive method for the quantitation of microgram quantities of protein utilizing the principle of protein-dye binding. Anal Biochem $72: 248-254$

24. Hinchliffe SA, Sargent PH, Howard CV, Chan YF, van Velzen D 1991 Human intrauterine renal growth expressed in absolute number of glomeruli assessed by the dissector method and Cavalieri principle. Lab Invest 64:777-784

25. Nyengaard JR, Bendtsen TF 1992 Glomerular number and size in relation to age, kidney weight, and body surface in normal man. Anat Rec 232:194-201

26. Nyengaard JR 1999 Stereologic methods and their application in kidney research. J Am Soc Nephrol 10:1100-1123

27. Waugh WH 1977 Photometry of inulin and polyfructosan by use of a cysteine/ tryptophan reaction. Clin Chem 23:639-645

28. Brun C 1951 A rapid method for the determination of para-amino-hippuric acid in kidney function tests. J Lab Clin Med 37:955-958

29. Larsson L, Aperia A, Wilton P 1980 Effect of normal development on compensatory renal growth. Kidney Int 18:29-35

30. Langley-Evans SC, Jackson AA 1995 Captopril normalises systolic blood pressure in rats with hypertension induced by fetal exposure to maternal low protein diets. Comp Biochem Physiol 110A:223-228

31. Langley-Evans SC, Welham SJM, Sherman RC, Jackson AA 1996 Weanling rats exposed to maternal low-protein diets during discrete periods of gestation exhibit differing severity of hypertension. Clin Sci 91:607-615

32. Zhang DY, Lumbers ER, Simonetta G, Wu JJ, Owens JA, Robinson JS, McMillen IC 2000 Effects of placental insufficiency on the ovine fetal renin-angiotensin system. Exp Physiol 85:79-84

33. Merlet-Benichou C, Gilbert T, Muffat-Joly M, Lelievre-Pegorier M, Leroy B 1994 Intrauterine growth retardation leads to a permanent nephron deficit in the rat. Pediatr Nephrol 8:175-180
34. Zeman FJ 1968 Effects of maternal protein restriction on the kidney of the newborn young of rats. J Nutr 94:111-116

35. Langley-Evans SC, Welham SJM, Jackson AA 1999 Fetal exposure to a maternal low protein diet impairs nephrogenesis and promotes hypertension in the rat. Life Sci 64:965-974

36. Madsen K 1999 The art of counting. J Am Soc Nephrol 10:1124-1125

37. Hanson MA, Hawkins P, Ozaki T, Steyn C, Matthews SG, Noakes D, Poston L 1999 Effects of experimental dietary manipulation during early pregnancy on cardiovascular and endocrine function in fetal sheep and young lambs. In: O'Brien PMS, Wheeler T, Barker DJP (eds) Fetal Programming: Influences on Development and Disease in Later Life. RCOG Press, London, pp 365-373

38. Holemans K, Gerber R, Meurrens K, De Clerck F, Poston L, Van Assche FA 1999 Maternal food restriction in the second half of pregnancy affects vascular function but not blood pressure of rat female offspring. Br J Nutr 81:73-79

39. Clark AF, Sharp MGF, Morley SD, Fleming S, Peters J, Mullins JJ 1997 Renin-1 is essential for normal renal juxtaglomerular cell granulation and macula densa morphology. J Biol Chem 272:18185-18190

40. Nishimura H, Yerkes E, Hohenfellner K, Miyazaki Y, Ma J, Hunley TE, Yoshida H, Ichiki T, Threadgill D, Phillips III JA, Hogan BM, Fogo A, Brock III JW, Inagami T, Ichikawa I 1999 Role of the angiotensin type 2 receptor gene in congenital anomalies of the kidney and urinary tract, CAKUT, of mice and men. Mol Cell 3:1-10

41. Okubo S, Niimura F, Matsusaka T, Fogo A, Hogan BL, Ichikawa I 1998 Angiotensinogen gene null-mutant mice lack homeostatic regulation of glomerular filtration and tubular reabsorption. Kidney Int 53:617-625

42. Tsuchida S, Matsusaka T, Chen X, Okubo S, Niimura F, Nishimura H, Fogo A, Utsunomiya H, Inagami T, Ichikawa I 1998 Murine double nullizygotes of the angiotensin type $1 \mathrm{~A}$ and $1 \mathrm{~B}$ receptor genes duplicate severe abnormal phenotypes of angiotensinogen nullizygotes. J Clin Invest 101:755-60

43. Fogo A, Yoshida Y, Yared A, Ichikawa I 1990 Importance of angiogenic action of angiotensin II in the glomerular growth of maturing kidneys. Kidney Int 38:10681074

44. Friberg P, Sundelin B, Bohman S-O, Bobik A, Nilsson H, Wickman A, Gustafsson H, Petersen J, Adams MA 1994 Renin-angiotensin system in neonatal rats: induction of a renal abnormality in response to ACE inhibition or angiotensin II antagonism. Kidney Int 45:484-492

45. Tufro-McReddie A, Johns DW, Geary KM, Dagli H, Everett AD, Chevalier RL, Carey RM, Gomez RA 1994 Angiotensin II type 1 receptor: role in renal growth and gene expression during normal development. Am J Physiol 266:F911-F918

46. Tufro-McReddie A, Romano LM, Harris JM, Ferder L, Gomez RA 1995 Angiotensin II regulates nephrogenesis and renal vascular development. Am J Physiol 269:F110 F115

47. Brenner BM, Garcia DL, Anderson S 1988 Glomeruli and blood pressure. Less of one, more the other? Am J Hypertens 1:335-347

48. Hostetter TH, Olson JL, Rennke HG, Venkatachalam MA 1981 Hyperfiltration in remnant nephrons: a potentially adverse response to renal ablation. Am J Physiol 241:F85-F93

49. Meyer TW, Rennke HG 1988 Progressive glomerular injury after limited renal infarction in the rat. Am J Physiol 254:F856-F862

50. Seckl JR, Benediktsson R, Lindsay RS, Brown RW 1995 Placental $11 \beta$ hydroxysteroid dehydrogenase and the programming of hypertension. J Steroid Biochem Molec Biol 55:447-455

51. Benediktsson R, Lindsay RS, Noble J, Seckl JR, Edwards CRW 1993 Glucocorticoid exposure in utero: new model for adult hypertension. Lancet 341:339-341

52. Langley-Evans SC 1997 Maternal carbenoxolone treatment lowers birthweight and induces hypertension in the offspring of rats fed a protein-replete diet. Clin Sci 93:423-429

53. Lindsay RS, Lindsay RM, Edwards CRW, Seck1 JR 1996 Inhibition of $11 \beta$ hydroxysteroid dehydrogenase in pregnant rats and the programming of blood pressure in the offspring. Hypertension 27:1200-1204

54. Langley-Evans SC, Phillips GJ, Benediktsson R, Gardner DS, Edwards CRW, Jackson AA, Seckl JR 1996 Protein intake in pregnancy, placental glucocorticoid metabolism and the programming of hypertension in the rat. Placenta 17:169-172

55. Segar JL, Bedell K, Page WV, Mazursky JE, Nuyt A-M, Robillard JE 1995 Effect of cortisol on gene expression of the renin-angiotensin system in fetal sheep. Pediatr Res 37:741-746

56. Celsi G, Kistner A, Aizman R, Eklof A-C, Ceccatelli S, De Santiago A, Jacobson SH 1998 Prenatal dexamethasone causes oligonephronia, sodium retention, and higher blood pressure in the offspring. Pediatr Res 44:317-322 